\title{
Miranda
}

Revue pluridisciplinaire du monde anglophone /

Multidisciplinary peer-reviewed journal on the English-

speaking world

$21 \mid 2020$

Modernism and the Obscene

\section{"It's Time for the System to be Refigured": An Interview with Playwright Marcus Scott}

Interview

\section{Raphaëlle Tchamitchian}

\section{(2) OpenEdition}

\section{Journals}

\section{Electronic version}

URL: http://journals.openedition.org/miranda/30768

DOI: 10.4000/miranda.30768

ISSN: 2108-6559

\section{Publisher}

Université Toulouse - Jean Jaurès

\section{Electronic reference}

Raphaëlle Tchamitchian, "IIt's Time for the System to be Refigured": An Interview with Playwright Marcus Scott", Miranda [Online], 21 | 2020, Online since 19 October 2020, connection on 16 February 2021. URL: http://journals.openedition.org/miranda/30768 ; DOI: https://doi.org/10.4000/miranda. 30768

This text was automatically generated on 16 February 2021.

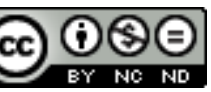

Miranda is licensed under a Creative Commons Attribution-NonCommercial-NoDerivatives 4.0 International License. 


\title{
"It's Time for the System to be Refigured": An Interview with Playwright Marcus Scott
}

Interview

\author{
Raphaëlle Tchamitchian
}

\section{Weblinks}

Marcus Scott website: https://writemarcus.tumblr.com/

\section{Biography of the Interviewee}

Marcus Scott is a playwright, musical theater writer, librettist, journalist, blogger critic and teaching artist. His work includes the musical Cherry Bomb, the opera Fidelio (which was called "urgent, powerful, and poignant" by The New York Times and "imaginative, vital, and heartbreaking" by The New Yorker), and the plays Tumbleweed, Natural Selection, Blood Orange, Double Rainbow and Malaise. His work has notably received readings or development at Joe's Pub, 54 Below, Cherry Lane Theater (Downtown Urban Arts Festival), Theater 80 St. Marks (Downtown Urban Arts Festival) and New York Musical Theatre Festival (at the Pershing Square Signature Theatre). And his writing has appeared in American Theatre, Soule, Elle, Out, Essence, Playbill, Broadway Black, among others.

\section{The Interview}


Fig 1

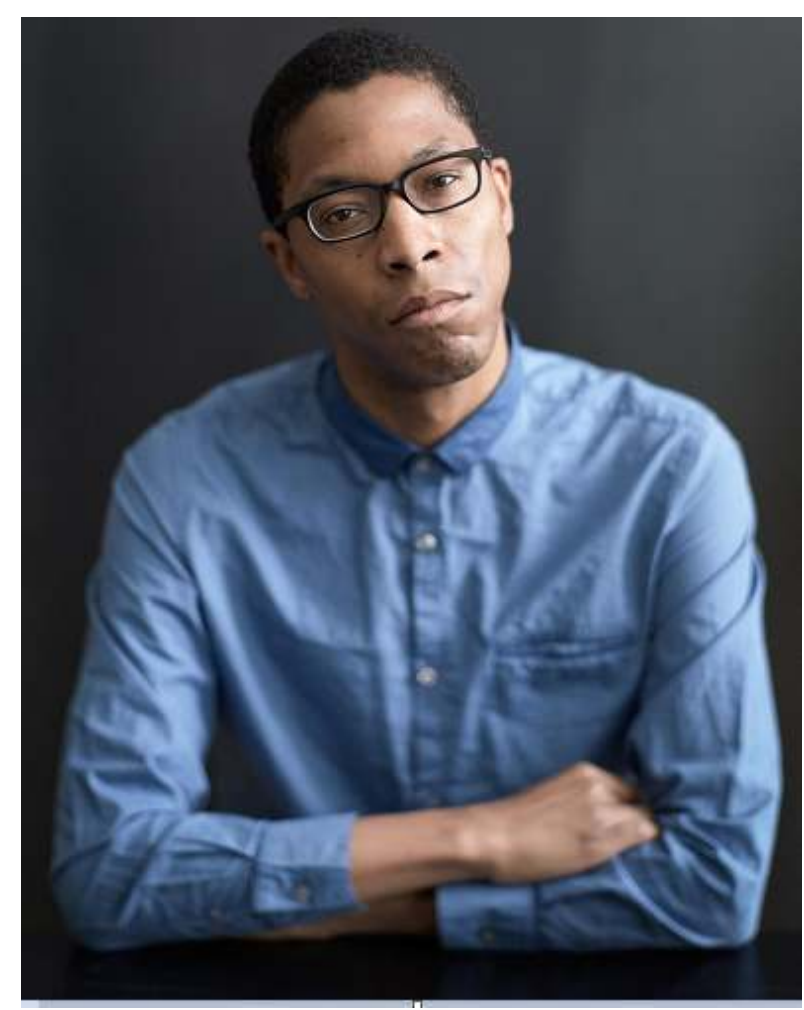

Marcus Scott.

Credits: Thomas Dunn

Raphaëlle Tchamitchian: What is happening right now in New York City regarding the sanitary crisis? Are venues expected to reopen anytime soon?

Marcus Scott: The city was supposed to open in July, but everything's been pushed back until February 2021 with a hard open probably around April, because we're expecting a second or third wave of the pandemic. In terms of what's happening in the industry, the Tony Awards are going to take place digitally this Fall for the first time. They've just announced the nominees. In terms of my own personal journey, I've lost out on a lot of different opportunities, including things that would have changed my career. I lost an opportunity for an opera that I wrote, that was supposed to premiere at the Baltimore Symphony Orchestra. I lost out an opportunity for a play of mine to premiere at the Signature Theatre here in New York. Throughout this process though, I've been commissioned to write short musicals for a digital format. Because of Zoom, that has its own style written into it, my writing is changing: characters are not jumping from scene to scene as much, they all talk to the camera, and a lot of plays are monologues or two-handers.

RT: Like the rest of the country, American theatre is going through a political and racial crisis. How is Black Lives Matter changing theatre?

Marcus Scott: Right now, different establishments in America are going through a rude awakening. BIPOC (Black and Indigenous People of Color) are coming out from the woodwork. Some of the most interesting artwork is done by women and people of color, and we very much feel there's not a lot of opportunities for us. In America, before Hamilton, $82 \%$ of the people getting produced in theaters around the country were white men. In a post-Hamilton world, about five years later, this number has 
gone down to $70-72 \%$ of white men. That leaves $28-30 \%$ to all the other groups of people, warring up in the margins: women, people of color, black people, indigenous people, queer people, trans people, people who have different bodies... They're all fighting for the "token spot": the room left by white cis males for one woman, one black person, one Native American, etc. In the theater community, people are really fighting back.

\section{RT: How is the fight taking place?}

Marcus Scott: People are connecting within communities. For instance, we've had our very first Antonyo Awards ${ }^{1}$, digitally hosted by Broadway Black ${ }^{2}$, a media company that promotes black theatre and reports on what's happening in the black community. Awards were only given to black artists, and the whole show looked at our accomplishments from the very beginning in Tin Pan Alley. It was a very popular broadcast, but also divisive because there wasn't a lot of categories; it was very much an actor's award as opposed to a writer's or a composer's award. But point of the matter, the Antonyo Awards looked at the dearth of opportunity for black people on Broadway and in American theater. For example, one technical award (of two) was given to the only person who was working on that role, because there's only one black person working in that one role on Broadway.

A number of other tools are being activated, like The Kilroy's, a collective of LA and NYC playwrights, directors and producers, that issue a yearly list of the most exciting and worth-producing plays by women, trans and non-binary playwrights ${ }^{3}$. The Lilys ${ }^{4}$ also support and honor women, and they initiated The Count ${ }^{5}$, which studies diversity within regional theaters seasons. Finally, there is a list for Asian American theatre.

RT: Can you speak about the new coalition of BIPOC theatre artists "We See You White American Theatre"?

Marcus Scott: Yes, so "We See You White American Theatre" published a 31-page long manifesto ${ }^{6}$ about a month ago signed by people like actress Audra McDonald (a multiple Tony Awards winner), Oscar-winning actress Viola Davis and playwright Lynn Nottage (two-times winner of the Pulitzer Prize). Within the community, while a lot of people have given unbridled support to the movement, there is some opposition, sometimes even animosity-see for instance the lengthy paper issued by Tony Award winner actress Tonya Pinkins? .

There are two schools of thought. First, armchair activists who are speaking out and demanding certain things in a very politicized way. Second, people who emphasize the action part of the fight. Demands are great but, outside of saying "this is not fair," what are you doing physically? Are you marching on the streets? Are you unionizing black talent? Outside of the movement helping you, how are you helping the person behind you?

\section{RT: I'm guessing you're part of the second school...}

Marcus Scott: I am. I marched during Occupy Wall Street, I spoke out for Black Lives Matter, I took the streets, I signed petitions, I went to offices and talked to people... I used my platforms as a journalist, as a playwright and as a concerned citizen. I find that we can make as many lists of demands as we want, we firstly have to do something. Some of the demands of "We See You White American Theatre" are overkill. One of the things they want people to do is acknowledge we all live and work 
on Indigenous and Native American land: I love that people are acknowledging it, I get it, but anybody who reads a history book knows it was stolen. So what are we doing beyond that? We should be giving money and resources, giving Native Americans work, commissioning indigenous talent, offering free tickets to indigenous people kids. I feel there's a lot of manufacturing wokeness and there's a lot of wokewashing that's going on right now in the theater community-and by "wokewashing" I mean theaters or companies that will give money for a particular month or a particular moment and then disappear". I find that, to a certain extent, "We See You White American Theatre" is telling people to feel a certain way instead of having a conversation. A lot of liberals are not making any compromise, and are refusing to have a dialogue with conservatives, and vice versa. There is also a lot of centrist behavior afraid to take sides-and a lot of that is because people are behind a screen.

RT: Is the "We See You White American Theatre" movement getting responses from theater leaders?

Marcus Scott: A lot of theater heads are stepping down, and a new group of people are coming in. Usually they're also white men or white women, but they're younger and a little bit more "hip." There are also diversity and inclusion hires, but a lot of the BIPOC people coming in are either interns or fellows, either doing managing, technical or administrative jobs. Rarely are these people on the artistic side.

But the biggest change is that the American theatre subscriber base is changing almost overnight. Traditionally, the biggest subscriber base (regional theaters and Broadway alike) is white middle-aged middle-class women from the boomer generation or generation $\mathrm{X}$. That kind of base has views rooted in a certain type of racism, which is why theaters are not producing the most challenging and artistically fulfilling works. Today, we're trying to diversify the people who are coming into the theater by giving initiatives to students of color and free seats for black creators. There is a lot more of an outcry for BIPOC critics as well.

My biggest critique though is that we are not holding BIPOC institutions to their standard right now. I'm seeing a lot of people attacking predominantly white institutions (as they should be) but not holding black-particularly black because I'm black-institutions accountable. Yet, those institutions sometimes uphold white supremacist practices. For instance, a lot of BIPOC theaters, while doing performative work for the community, won't pay attention to a black playwright until a white institution validates them. Most of them don't have a lot of money (white institutions may have millions of dollars per year, and a lot of BIPOC theaters will have at most two million dollars, which is not a lot of money), so they have to make strategic decisions. Often, they will have a windfall, the one event that they know everyone's gonna be at no matter what they do, and next to that they will produce programs for emerging talent. But a lot of the time these emerging talents are people who have been around for years and have been validated by white institutions. They are not bringing in people who frankly have the right kind of acumen.

RT: Doesn't that have as much to do with capitalism-not taking risks for money-as it has to do with racism?

Marcus Scott: It's definitely capitalism but capitalism doesn't exist without white supremacy; they're both connected. The value of the black dollar is huge: if black people around the world took one day off, we would take down the global economy. Whether in cinema (Spike Lee, Viola Davis, Angela Bassett, Lee Daniels, Jordan Peele, 
Tyler Perry) or in music (Beyoncé, Rihanna, Lizzo, Megan Thee Stallion, Janelle Monáe-and those are just black women!), we're killing it right now. We are the most subjugated and demonized people worldwide, and yet at the same time, in a really weird way, people still take black art, fashion and influence in their work-it boggles my mind. In theatre, the person who had the Pulitzer Prize for Drama this year is a black gay man from Detroit who wrote a musical he's been working in the trenches for 16 years $^{9}$. He is the person everyone is looking to right now as the voice of American theatre. Several black playwrights are transitioning to television and film. One of the most profitable plays last year on Broadway was Jeremy O. Harris' Slave Play. When you compare all that to the fact we are among the $30 \%$ of people who are warring in the margins, it's repugnant. So it's not enough to say: "it's capitalism." Now we're having a moment, so people want to give two or three spots to black and brown creatives... it's upsetting because we've been saying this for years. As black creators in particular, we have to respond to anti-blackness, to police brutality we're seeing en masse on television every day, while also fighting for our lives. This is systemic, this is happening everywhere-you're a part of it as well.

RT: What do you think theater as an art form can do politically? On the one hand, one might believe art cannot have any real political effect on life, because the fight occurs on the streets or in unions; on the other hand, one might think art is political in itself, formally and aesthetically, when it challenges pre-existing notions of what it should be or say. Where do you stand on that matter, regarding theatre in particular?

Marcus Scott: I stand on the latter. Art is fundamental. I would not be an artist if I believed otherwise (there's not enough money! Often, I'm coming from my pocket to create my own art). Art can insight change. There are political exiles from all over the world in America right now who would be murdered on the spot if they're in their country. In America we've had people blacklisted during McCarthyism because they wrote something or acted in something. I mentioned Slave Play earlier: people, particularly white people, felt like they were being attacked. During a talk back, a woman stood up and yelled at the playwright; she was escorted out of the theater. Sweat by Lynn Nottage, which won the Pulitzer Prize, is about the economic bubble bursting in Pennsylvania. The Cost of Living by Martyna Majok, which also won the Pulitzer, is about people who are enduring a life with a disability and are looking for love and looking to be acknowledged as sexual beings. Those plays created conversations that people weren't having. Beyoncé's Homecoming celebrated blackness's wealth, riches and contributions during two hours. A lot of black children cried when Chadwick Boseman died: by playing Black Panther, he affirmed us; he told us we could be superheroes too. We couldn't do that without art. Other institutions can't do that. Medicine cures, but how do you learn that you can be a doctor? Most often through some kind of media.

RT: Does that mean you think what theatre can do politically is put black narratives on stage?

Marcus Scott: It's more putting BIPOC, as well as trans and queer people, on creative teams to de-center whiteness. We have been on stage, so it's about doubling the amount of BIPOC creatives in order to get rid of the "token spot." Globally, there are more people who look like me than people who look white: put those stories centerstage. I'm not saying that we should be the ones taking over; I'm saying that theatre needs to reflect the world we live in. Put more people of color, and change up the subject matters as well. It's time for the system to be refigured. 
RT: Well, thank you so much for your time and generosity.

Marcus Scott: Thank you for interviewing me, it's an honor.

\section{NOTES}

1. Broadway Black. "Broadway Black Presents the Inaugural Antonyo Awards." Youtube. Online June 19, 2020. Last accessed October 5, 2020.

<URL Address https://www.youtube.com/watch?v=zWtY4nNDFbU>

2. Broadway! Black. When Theatre Goes Dark. Last accessed October 5, 2020.

<URL Address https://www.broadwayblack.com/>

3. The Kilroys. Last accessed October $5,2020$.

<URL Address https://thekilroys.org/>

4. The Lillys. Last accessed October 5, 2020.

<URL Address https://the-lillys.org/>

5. The Lillys. "The Count." Last accessed October 5, 2020.

<URL Address https://the-lillys.org/the-count-1>

6. We See You White American Theatre. "BIPOC Demands For White American Theatre." Last accessed October 5, 2020.

<URL Address https://www.weseeyouwat.com/>

7. Pinkins, Tonya. "Why I Am Fed Up With Performative Activism From White and Black Theater Makers." Medium. Online July 10, 2020. Last accessed October 5, 2020.

$<$ URL Address https://medium.com/@tonyapinkins/why-i-am-fed-up-with-performativeactivism-from-white-and-black-theater-makers-d46564ec94fe>

8. Born within the context of Black Lives Matter, the term « woke » refers at first to a state of consciousness and alert vis-à-vis the oppression and marginalization of minorities, especially black. Its usage has then spread to larger political and sometimes mundane contexts.

9. Michael R. Jackson for A Strange Loop.

\section{ABSTRACTS}

Interview with African American playwright Marcus Scott about the political and racial crisis in American theatre. Led via Skype on September 4th, 2020.

Entretien avec le dramaturge africain américain Marcus Scott autour de la crise politique et raciale du théâtre américain. Mené par Skype le 4 septembre 2020. 
INDEX

Keywords: Marcus Scott, American theatre, black theatre, Broadway, We See You White American Theatre, crisis, race relations, BIPOC

Mots-clés: Marcus Scott, théâtre américain, théâtre noir, Broadway, We See You White American Theatre, crise, relations raciales, BIPOC

Subjects: Theater

\section{AUTHOR}

\section{RAPHAËLLE TCHAMITCHIAN}

$\mathrm{PhD}$ in Theatre Studies

Associated member of lab. SeFeA/IRET - Université Sorbonne Nouvelle

raphaelle@epistrophy.fr 